\title{
Meridional Extent and Interannual Variability of the Pacific Ocean Tropical-Subtropical Warm Water Exchange
}

\author{
Christopher S. Meinen \\ Cooperative Institute for Marine and Atmospheric Studies, University of Miami, Miami, Florida
}

(Manuscript received 22 October 2003, in final form 2 July 2004)

\begin{abstract}
Altimetric observations of sea surface height anomaly (SSHA) from the TOPEX/Poseidon and ERS satellites, hydrography, and the ECMWF and Florida State University wind products are used to track warm water $\left(\geq 20^{\circ} \mathrm{C}\right)$ as it is exchanged between the equatorial Pacific Ocean and the higher latitudes during 1993-2003. The large El Niño event of 1997-98 resulted in a significant discharge of warm water toward the higher latitudes within the interior of the Pacific Ocean. The exchange of anomalous warm water volume with the Northern Hemisphere appears to be blocked under the intertropical convergence zone, consistent with most current ideas on the time-mean tropical-subtropical exchange. Little of the warm water discharged northward across $5^{\circ}$ and $8^{\circ} \mathrm{N}$ during the 1997-98 El Niño event could be traced as far as $10^{\circ} \mathrm{N}$. To the south, however, these anomalous volumes of warm water were visible at least as far as $20^{\circ} \mathrm{S}$, primarily in the longitudes around $130^{\circ}-160^{\circ} \mathrm{W}$. In both hemispheres most of the warm water appeared to flow westward before returning to the Tropics during the recharge phase of the El Niño-La Niña cycle. The buildup of warm water in the Tropics before the 1997-98 El Niño is shown to be fed primarily by warm water drawn from the region in the western Pacific within $5^{\circ} \mathrm{S}-15^{\circ} \mathrm{N}$. The exchange cycle between the equatorial band and the higher latitudes north of the equator leads the cycle in the south by 6-8 months. These results are found in all three datasets used herein, hydrography, altimetric observations of SSHA, and Sverdrup transports calculated from multiple wind products, which demonstrates the robustness of the results.
\end{abstract}

\section{Introduction}

The dominant circulation patterns in the interior of the equatorial Pacific Ocean are primarily zonal, including the westward-flowing North and South Equatorial Currents (NEC and SEC, respectively), as well as the eastward-flowing North Equatorial Countercurrent (NECC) and Equatorial Undercurrent (e.g., Tomczak and Godfrey 1994). Masked by these zonal flows are meridional overturning cells, consisting of poleward Ekman flows in the upper 40-50 $\mathrm{m}$ and equatorward geostrophic flow at main thermocline depth levels of roughly 50-200 m (e.g., McCreary and Lu 1994). These meridional cells have significant impacts on the meridional heat fluxes in the atmosphere-ocean system (e.g., Klinger and Marotzke 2000); recent atmospheric reanalyses have suggested that the net atmosphere-ocean poleward heat transport is dominated by the ocean equatorward of $17^{\circ} \mathrm{N}$ and $17^{\circ} \mathrm{S}$ (Trenberth and Caron 2001). Ocean models suggest that variations of these cells may also result in significant variability in equatorial sea surface temperatures (Kleeman et al. 1999;

Corresponding author address: Dr. Christopher S. Meinen, NOAA/Atlantic Oceanographic and Meteorological Laboratory, 4301 Rickenbacker Causeway, Miami, FL 33149.

E-mail: christopher.meinen@noaa.gov
Nonaka et al. 2002). The existence of these subtropicaltropical cells (STCs) is well known; however, the details of the circulation pathways have proven elusive due to the difference in magnitudes of the zonal and meridional flows. Furthermore, there is some evidence that the STCs may exhibit significant interannual and decadal variability (Meinen and McPhaden 2001; McPhaden and Zhang 2002).

Widely scattered sea-level observations suggest that during El Niño events warm water flows poleward away from the equatorial Pacific (Wyrtki 1975) and warm water returns to the equatorial band during La Niña events. Simple coupled models have suggested that exchange of heat content between the equatorial band and the higher latitudes is a fundamental effect of the interaction of equatorial and nonequatorial Rossby and Kelvin waves that drive the oceanic component of the El Niño-Southern Oscillation (ENSO) system (e.g., Zebiak 1989). Observational evidence has shown that during the 1997-98 El Niño event the warm water volume (WWV, defined as waters with temperatures greater than $20^{\circ} \mathrm{C}$ ) within $5^{\circ} \mathrm{S}-5^{\circ} \mathrm{N}$ in the Pacific decreased by roughly $25 \%$ (Meinen and McPhaden 2000). Furthermore, a warm water volume balance has demonstrated that the diapycnal transports across $20^{\circ} \mathrm{C}$ (approximated by the diathermal transport) are small 
(Meinen et al. 2001), and interannual variations of the net (Ekman plus geostrophic) meridional transport in the ocean interior across $8^{\circ} \mathrm{S}$ and $8^{\circ} \mathrm{N}$ are significant, $\geq 20 \mathrm{~Sv}\left(\mathrm{~Sv} \equiv 10^{6} \mathrm{~m}^{3} \mathrm{~s}^{-1}\right)$, concurrent with El Niño and La Niña events (Meinen and McPhaden 2001). These anomalous poleward and equatorward flows of warm water occur at thermocline depths and above, suggesting that modifications of the STCs are occurring at interannual time scales (whether as a change to the vertical structure of the cells or as a change to one or more components of the cells). This then implies significant interannual variations in the meridional heat fluxes are occurring in the ocean.

The three-dimensional pathways and mechanisms involved in these interannual variations in warm water exchange between the Tropics and the subtropics have not yet been fully explained nor has the meridional extent of the exchange been quantified. Some progress has been made toward determining the time-mean circulation pathways using widely scattered (temporally and spatially) CTD data as well as with satellite measurements (e.g., Johnson and McPhaden 1999; Bonjean and Lagerloef 2002); however, the details of the exchange, and in particular the meridional extent of the communication with the subtropics and the time variability of the pathways, has been difficult to determine due to data limitations. Analytical and numerical modeling studies have also made significant efforts toward understanding the STCs (e.g., Pedlosky 1991; Liu 1994; Liu et al. 1994; Rothstein et al. 1998; Huang and Liu 1999; Coles and Rienecker 2001). These model studies have provided insights, not always consistent with one another, into the pathways of the time-mean STCs; however, without observations to confirm these model results, it is difficult to know which models to believe. The modeling studies have also tended to focus on the time-mean STC pathways, noting that variability is an important area for future work (e.g., Rothstein et al. 1998).

Direct observations of the subsurface temperature are not available from enough of the tropical and subtropical Pacific Ocean, with enough temporal resolution, to allow direct estimates of the movement of WWV. Because changes in the ocean heat content affect the sea surface height ( $\mathrm{SSH})$, however, it is possible to use satellite altimetry measurements of sea surface height anomaly (SSHA) to track the movement of the warm water. It will be shown shortly that, at least with the limited subsurface temperature available for testing the relationship, the correlation between SSHA and WWV between $30^{\circ} \mathrm{S}$ and $30^{\circ} \mathrm{N}$ in the Pacific Ocean is quite high. The purpose of this study is to describe the interannual variations of the exchanges between the equatorial band and the higher latitudes during 19932003. While the main focus of this paper is on the poorly known meridional flows, it will be shown that the pathways of interannual variability are not purely meridional, so the zonal flows will be discussed where appropriate. The primary dataset used is the blended altimetry measurements from the Ocean Topography Experiment (TOPEX)/Poseidon satellite and European Remote Sensing Satellite (ERS); however, two additional independent datasets will be used to confirm and build upon the altimeter results. It should also be noted that the usage of the terms "subtropical" and "tropical" herein follows the oceanography sense for those terms, referring to oceanic gyres and not the geographic boundaries of the tropics of Cancer and Capricorn.

\section{Data}

Five primary datasets were used in this study. The first, the volume of warm water in the tropical Pacific, was calculated following the methods presented in Meinen and McPhaden (2000) using gridded surface and subsurface temperature measurements provided by the Bureau of Meteorology Research Center (BMRC), Australia (Smith 1995a,b). The BMRC dataset combines XBT data with data from moorings, where available, using an optimal interpolation (OI) process to create a gridded dataset with monthly values at every $1^{\circ}$ of latitude and $2^{\circ}$ of longitude at a set of 14 depths between the surface and $500 \mathrm{~m}$. Since about 1993, roughly three-quarters of the subsurface temperature information in the BMRC Pacific data analysis between $5^{\circ} \mathrm{S}$ and $5^{\circ} \mathrm{N}$ derives from the Tropical Atmosphere and Ocean (TAO) Array (Smith and Meyers 1996; McPhaden et al. 1998). At latitudes poleward of $8^{\circ} \mathrm{S}$ and $8^{\circ} \mathrm{N}$ the observations used in the BMRC optimal interpolation process are primarily from repeat XBT lines, which are comparatively much more sporadic in time and space than observations from the TAO moorings (Smith and Meyers 1996).

The second dataset used herein is the altimetry measurements of sea surface height anomaly (SSHA) produced by the Collecte Localisation Satellites (CLS) Space Oceanography Division in France. The CLS dataset is a blended product utilizing data from the TOPEX/Poseidon and ERS-2 satellites. The dataset, which presents weekly mean SSHA on a $13^{\circ}$ grid, was obtained from the CLS Web page (online at http:// www.cls.fr). Further information on this dataset is available at that Web site.

Two different wind products were used in this study. The Florida State University (FSU) wind dataset, which combines measurements from ships and buoys, provides monthly wind pseudostress on a $2^{\circ}$ by $2^{\circ}$ grid. These data are provided by The Florida State University via their Web site (online at http://www.coaps.fsu. edu/WOCE/SAC/pacwinds.html). The FSU pseudostress was converted to stress using a drag coefficient of $1.20 \times 10^{-3}$ (Sirven et al. 1998). A second wind dataset was obtained from the European Centre for MediumRange Weather Forecasts (ECMWF). The ECMWF winds are on a $2.5^{\circ}$ by $2.5^{\circ}$ grid and are derived from an atmospheric general circulation model, which assimi- 
lates measurements from TAO buoy and ship winds as well as other data sources. The results from the ECMWF wind product were essentially the same as for the FSU winds, so only the FSU winds results will be presented herein.

A set of 4304 CTD profiles obtained within $20^{\circ} \mathrm{S}-$ $20^{\circ} \mathrm{N}$ during the 1990 s was obtained from the data archives at the Pacific Marine Environmental Laboratory (PMEL) in Seattle, Washington. All of these CTDs were quality controlled at PMEL, and each CTD reached at least $1000 \mathrm{dbar}\left(1 \mathrm{dbar}=10^{4} \mathrm{~Pa}\right)$.

The SSHA and WWV used in this study, as well as the FSU wind product, have had a mean seasonal cycle removed as follows. Using data from the time period 1993-96, monthly mean anomalies (with respect to the overall 1993-96 mean) were defined as seasonal "corrections," and these corrections were removed from the full time series of SSHA, WWV, and wind product to produce "seasonally corrected" time series. The years 1997-2003 were not used in developing the mean annual cycle to avoid aliasing any of the very large 199798 El Niño event (and the subsequent long La Niña event) into the mean seasonal cycle. After the removal of the mean seasonal cycle all time series were also smoothed with a 5-month running mean to eliminate higher-frequency signals.

\section{Background and methods}

\section{a. Background}

Meinen and McPhaden (2000) demonstrated that the WWV in the equatorial Pacific $\left(5^{\circ} \mathrm{S}-5^{\circ} \mathrm{N}, 120^{\circ} \mathrm{E}-80^{\circ} \mathrm{W}\right)$ decreased by about $25 \%$ during the 1997-98 El Niño event. Thinking of ENSO as a cycle, variations of WWV during the 1993-2003 time period were roughly a quarter cycle (7-9 months) out of phase with variations of the sea surface temperature anomaly (SSTA) integrated over the Niño-3 region (Fig. 1).

Integrated over $5^{\circ} \mathrm{S}-5^{\circ} \mathrm{N}, 150^{\circ}-90^{\circ} \mathrm{W}$ the Niño-3 SSTA is a commonly used proxy for the current state of the El Niño-La Niña cycle (Trenberth 1997). At the time of the highest SSTA in the eastern equatorial Pacific the tropical band experienced its peak rate of discharge of warm water. This is true for both the weak 1994-95 and 2002-03 El Niño events and the large

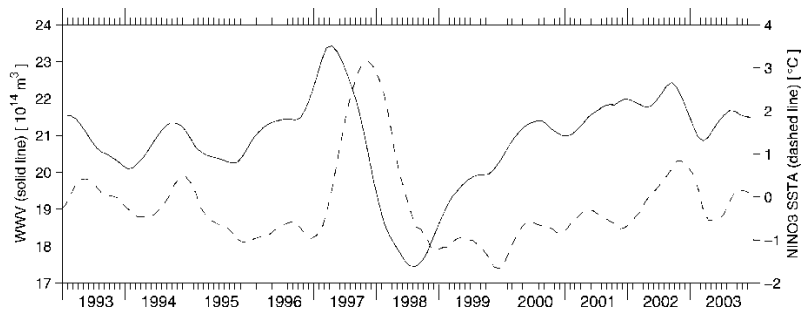

FIG. 1. Comparison of WWV ( $T \geq 20^{\circ} \mathrm{C}$, solid line) integrated within $5^{\circ} \mathrm{S}-5^{\circ} \mathrm{N}, 156^{\circ} \mathrm{E}-95^{\circ} \mathrm{W}$ with the sea surface temperature anomaly (SSTA, dashed line) integrated within the Niño-3 region $\left(5^{\circ} \mathrm{S}-5^{\circ} \mathrm{N}, 150^{\circ}-90^{\circ} \mathrm{W}\right)$.
1997-98 El Niño event. Some models have reproduced this WWV buildup prior to El Niño events and the discharge during events (e.g., Zebiak 1989), and the theoretical model of Jin (1997a,b) describes this recharge-discharge process as the controlling dynamics for the El Niño-La Niña cycle.

Meinen and McPhaden (2001) used observations of subsurface temperature, historical hydrography, and three different wind products to quantify the Ekman and geostrophic transports (the latter relative to a level of no motion at 1000 dbar) across $8^{\circ} \mathrm{S}, 8^{\circ} \mathrm{N}, 156^{\circ} \mathrm{E}$, and $95^{\circ} \mathrm{W}$ over the period $1993-99$. These transports show significant divergence of warm water from the tropical Pacific during El Niño events. These divergences are modified here to use $5^{\circ} \mathrm{S}$ and $5^{\circ} \mathrm{N}$ as the meridional boundaries for consistency with other analyses to be shown herein (Fig. 2).

The total divergence results primarily from the meridional component, with the zonal contribution being small and of nearly opposite phase. A phase difference between meridional interannual transport anomalies in the western boundary regime and flows in the ocean interior has been documented in a number of observational (e.g. Ueki et al. 2003) and modeling (e.g., Zebiak 1989; Lee and Fukumori 2003) studies. These studies have also demonstrated that the interior flow exceeds the western boundary anomalies, resulting in net meridional transports driven by the interior flows. Note that the lack of zonal divergence also indicates the discharge does not result from a large eastward flow toward the coast of the Americas and then a divergence
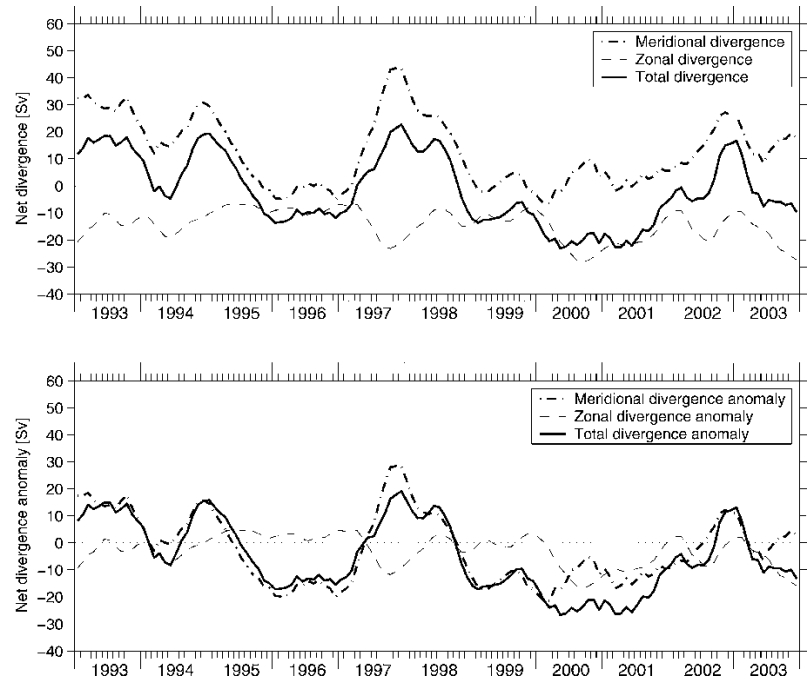

FIG. 2. (top) Net (Ekman + geostrophic) divergence of warm water from the equatorial band within $5^{\circ} \mathrm{S}-5^{\circ} \mathrm{N}, 156^{\circ} \mathrm{E}-95^{\circ} \mathrm{W}$. (bottom) Net divergence anomaly after the removal of the 199396 time mean. Meridional divergence is across $5^{\circ} \mathrm{S}$ and $5^{\circ} \mathrm{N}$; zonal divergence is across $156^{\circ} \mathrm{E}$ and $95^{\circ} \mathrm{W}$. Positive values represent a divergence; negative values indicate convergence. FSU wind product is used for calculating Ekman transports. Divergences are in Sverdrups. 


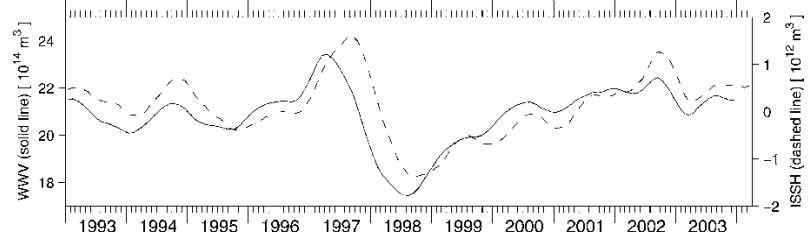

FIG. 3. Comparison of integrated WWV $\left(T \geq 20^{\circ} \mathrm{C}\right)$ with the ISSH. Integration region for both was $5^{\circ} \mathrm{S}-5^{\circ} \mathrm{N}, 156^{\circ} \mathrm{E}-95^{\circ} \mathrm{W}$. Solid line denotes WWV; dashed line denotes ISSH.

along the coast as was originally hypothesized by Wyrtki (1975) based on sea level observations. Meinen and McPhaden (2001) show the anomalous transport of warm water across $95^{\circ} \mathrm{W}$ is quite small over the 1993-99 period, and a recent study using the NCEP assimilation model has demonstrated over a longer period that the meridional flows along the eastern boundary are weak (Kug et al. 2003). The zonal convergences and divergences (Fig. 2) are mostly due to small changes in the flow into the interior from the western boundary across $156^{\circ} \mathrm{E}$ (Meinen and McPhaden 2001).

\section{b. Comparing $W W V$ and SSHA}

Moored subsurface temperature sensors are generally not available poleward of $8^{\circ} \mathrm{S}$ and $8^{\circ} \mathrm{N}$ in the Pacific during this time period and, while there are other in situ "time series" measurements such as repeat XBT lines, the temporal and spatial distributions are insufficient to repeat the analyses of Meinen and McPhaden (2001) at higher latitudes. There is, however, a global set of observations that have been collected continuously since late 1992 and can be used as a proxy for observing the WWV as it moves out of the Tropics: the SSHA observed by the TOPEX/Poseidon and ERS satellite altimeters. The blended CLS SSHA integrated over the same region as the WWV from Fig. 1 shows a very similar, although not identical, signal (Fig. 3).

The small differences in phasing are not statistically significant (given the filtering done to each time series), and the obvious phase offset during the 1997-98 El Niño event is dependent on which gridded altimetry product is used for determining the ISSH. The latter fact suggests that the different temporal sampling rates of the altimetry may be introducing a small amount of aliased noise into the gridded products. Note also that, while there is a noticeable lag during the 1997-98 El Niño event, there is essentially no lag between ISSH and WWV during the 2002-03 El Niño event. The lag between the two 1997-98 signals may also reflect the fact that the WWV is only including changes in the depth of the $20^{\circ} \mathrm{C}$ isotherm, while the integrated SSHA (ISSH) is affected by thermal changes through the full water column as well as by salinity changes. Comparing actual heat content integrated above the $20^{\circ} \mathrm{C}$ isotherm with WWV (and thus taking into account warming in the mixed layer, e.g.) explains at most one month of the observed lag. If $10^{\circ}$ or $15^{\circ} \mathrm{C}$ is used as the base of the volume integration, the lag between water volume and ISSH during the 1997-98 El Niño event is smaller, indicating a possible downward propagation of the equatorial divergence-convergence signal; however the overall time series correlation is also lower. Because the phase lag is smaller than the period of the box-car filter used to smooth the data, with the peak correlation $(r=0.90)$ at a 3-month lag, which is roughly half of the five month filter period; the lag between ISSH and WWV above $20^{\circ} \mathrm{C}$ is not statistically significant. This small lag is also shorter than the time scales of interest here, and the overall similarity between the two signals is quite evident, demonstrating that ISSH can be used to track the warm water expelled from the equatorial band during El Niño events.

As a further test of the ability of ISSH to predict WWV, a direct comparison of the ISSH, integrated in $1^{\circ}$ latitude by $4^{\circ}$ longitude bins, to the WWV integrated within those same bins can be made over the entire Pacific region where the BMRC dataset provides estimates of temperature. As noted above, however, outside of $8^{\circ} \mathrm{S}-8^{\circ} \mathrm{N}$ the BMRC dataset depends upon much less complete coverage (both temporally and spatially) than in the equatorial band (Smith and Meyers 1996). The resulting correlation field is rather noisy (Fig. 4).

Correlation between ISSH and WWV is high in the tropical band between $10^{\circ} \mathrm{S}$ and $5^{\circ} \mathrm{N}$ in the eastern $\mathrm{Pa}$ cific and between $15^{\circ} \mathrm{S}$ and $20^{\circ} \mathrm{N}$ in the western Pacific. The regions where the correlation is low, or negative, correspond closely to regions where there are little XBT data available (e.g., see Fig. 6 of Smith and Meyers 1996), particularly the eastern Pacific south of $15^{\circ} \mathrm{S}$ and the region just north of the "East Pacific Cold Tongue" near $9^{\circ} \mathrm{N}, 105^{\circ} \mathrm{W}$. The lack of correlation could result from either a real ocean difference in the two signals [such as local wind forcing and Ekman pumping affecting the SSH but not the WWV; e.g., Mayer et al. (2001)], or it could result from errors in one of the two datasets. In the northern subtropical Pacific it is clear that the lines of high correlation coincide with some of the repeat XBT line locations (e.g., the Hawaii to Philippines line). There is no physical process that would cause altimetry measurements to be correlated to the location of an XBT section; therefore this high correlation indicates that the BMRC subsurface temperature OI product is not accurately reproducing ocean variability in regions where XBT data are limited. This result suggests that the use of the BMRC subsurface temperature product for examining variability outside of frequently sampled regions should be undertaken with great caution. For the purposes of this paper, therefore, it will be assumed that ISSH tracks WWV closely; additional independent datasets will be compared to test results that rely on this assumption.

\section{c. SSHA variability}

Changes in WWV and SSHA within $5^{\circ} \mathrm{S}$ and $5^{\circ} \mathrm{N}$ are highly correlated. To use ISSH to track changes of 


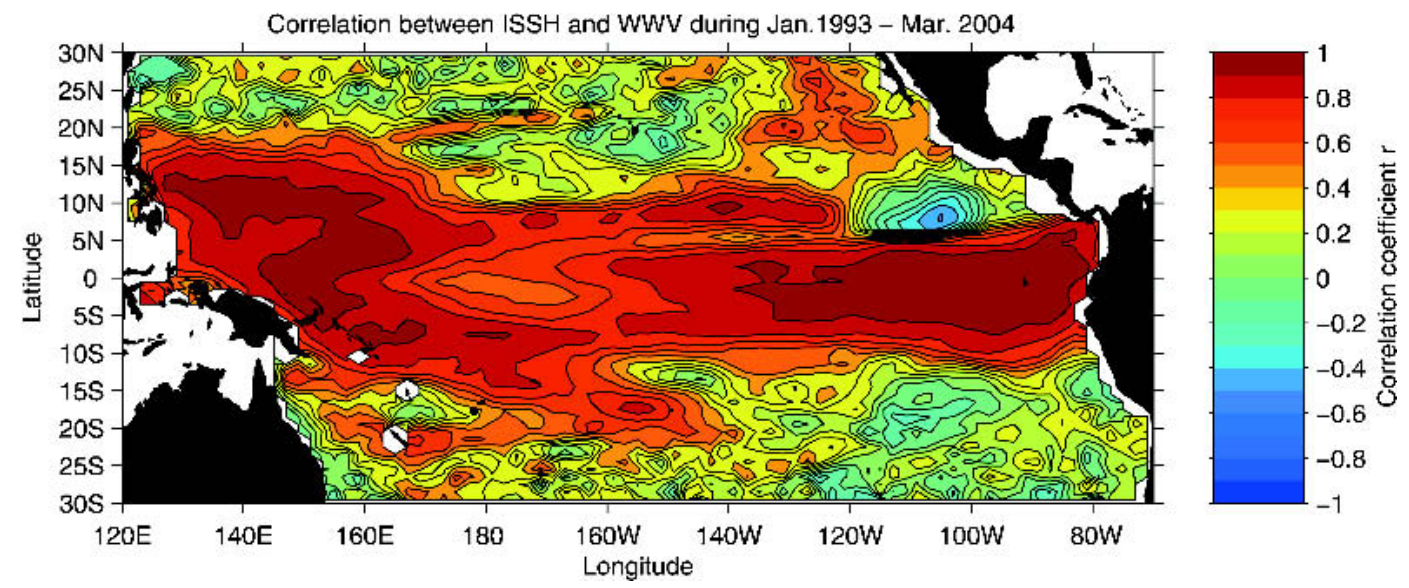

FIG. 4. Correlation coefficient $(r)$ between the ISSH and WWV integrated within the same $1^{\circ}$ by $4^{\circ}$ bins. Land is denoted by black filled regions.

WWV outside of the equatorial band the first task is to determine the proper regions over which to integrate the SSHA to get ISSH. The goal is to average over a big enough region to focus on the large-scale flows, but not over a region so big that the large scale transport signals are washed out. One method for determining the boundaries within which changes in SSHA are correlated is empirical orthogonal function (EOF) analysis (Emery and Thomson 1997). The structure of the first three resulting EOF modes is illustrated in Fig. 5.

These three EOF modes are very similar to those determined for the main thermocline depth (depth of the $20^{\circ} \mathrm{C}$ isotherm) by Meinen and McPhaden (2000) over the much longer 1980-99 time period. The amplitude of the first mode (Fig. 5a), which represents 20\% of the total variance, is largest along the equator between roughly $15^{\circ} \mathrm{S}$ and $15^{\circ} \mathrm{N}$ with a meridionally oriented nodal line at roughly $155^{\circ} \mathrm{W}$. There is always a risk in physically interpreting EOF modes, which are purely statistical constructs. That having been said, the first mode suggests that the largest component of the variability is associated with changes in the strength of the North and South Equatorial Currents and the exchange of warm water between the eastern and western Pacific. The temporal amplitude of mode 1 shows clear peaks associated with the 1994-95, 1997-98, and 200203 El Niño events (Fig. 6).

The peak in mid 1993 is roughly the same magnitude as the 1994-95 peak, but there is a bit of controversy about whether the 1993 peak was an El Niño event or whether it was part of a long El Niño event that involved the 1994-95 peak as well (Trenberth and Hoar 1996). Because the 1993, 1994-95 and 2002-03 El Niño events were so weak in comparison with the 1997-98 event, the rest of this paper will focus mostly on the 1997-98 event, with occasional mention of the smaller events.

The second EOF mode (Fig. 5b), which represents $9 \%$ of the total variance, is primarily a north-south tilt with a nodal line along $5^{\circ} \mathrm{N}$. The majority of the signal is confined within $15^{\circ} \mathrm{S}-15^{\circ} \mathrm{N}$ although it extends a bit farther south in the western Pacific. An earlier study using a shorter altimetric record in concert with a linear model indicated that variations of the second EOF mode of SSHA were primarily responsible for sea level fluctuations in the near-equator band (Alory and Delcroix 2002). Again under the caveat that EOF modes are not necessarily physical modes, the second mode appears to correspond to variations in the North Equatorial Countercurrent and the western boundary regime. The temporal amplitude of the second mode (Fig. 6 ) is very similar in character (correlation coefficient $=$ 0.87 ) to the time series of WWV in the equatorial band (Fig. 1), with the largest transition occurring during the peak of the 1997-98 El Niño. The third mode, which represents only $5 \%$ of the total variance, has a higher wavenumber structure with multiple positive peaks at $10^{\circ} \mathrm{S}$ and $30^{\circ} \mathrm{N}$ and multiple negative peaks at $25^{\circ} \mathrm{S}$ and $5^{\circ} \mathrm{N}$. These peaks in the structure are confined mainly to the western half of the Pacific. The third mode is of questionable statistical significance, and will not be discussed further.

The key result from these EOF analyses is that the variability of SSHA in the tropical and subtropical $\mathrm{Pa}$ cific occurs primarily in zonal bands of $5^{\circ}-10^{\circ}$ of latitude width with a meridional nodal line near $155^{\circ} \mathrm{W}$ for the first mode. This suggests that, by breaking the tropical Pacific into boxes of $5^{\circ}$ of latitude width $\left(10^{\circ}\right.$ wide at the equator) and splitting these boxes into western and eastern portions along $155^{\circ} \mathrm{W}$, the resulting ISSH integrations should primarily combine correlated regions of SSHA. ${ }^{1}$ Therefore, in order to quantify where the warm water moves once it leaves the equatorial region, the tropical and subtropical region was broken up into

\footnotetext{
${ }^{1}$ The results are not very sensitive to the precise choice of the east-west split longitude.
} 

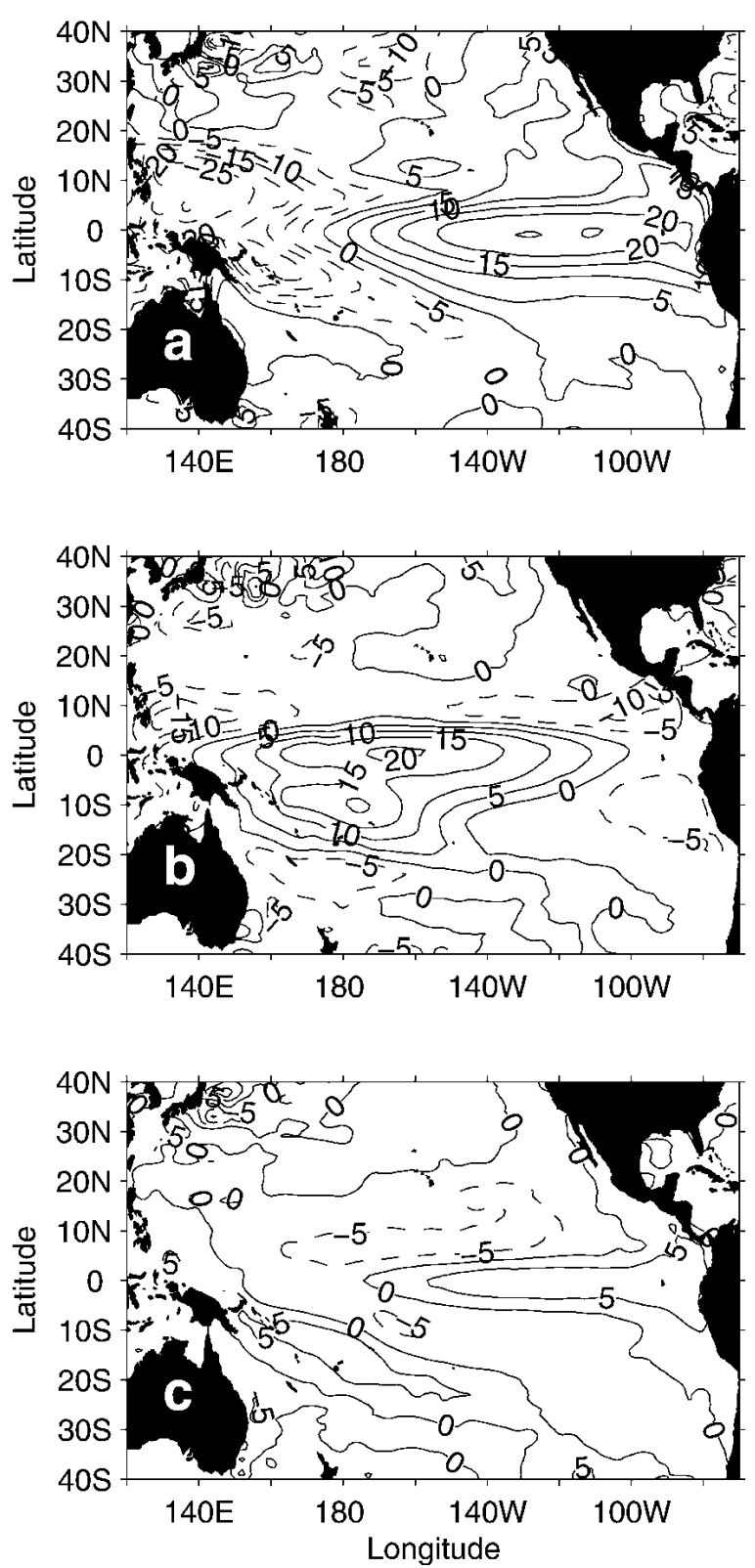

FIG. 5. EOF modes fit to the SSHA fields. (a) Mode 1, which represented about $20 \%$ of the total variance. (b) Mode 2, which represented about $9 \%$ of the total variance. (c) Mode 3, which represented about $5 \%$ of the total variance. Black areas indicate land; panel identifiers are placed within Australia. Units are centimeters.

11 separate latitude bands (all $5^{\circ}$ latitude wide except the band on the equator, which was $10^{\circ}$ wide). The latitude bands were further broken into western and eastern subregions along $155^{\circ} \mathrm{W}$. Within each of these 22 boxes the ISSH was calculated over the period 19932003, which spanned three El Niño events (1994-95, 1997-98, 2002-03) and two La Niña events (1995-96, 1998-2000).

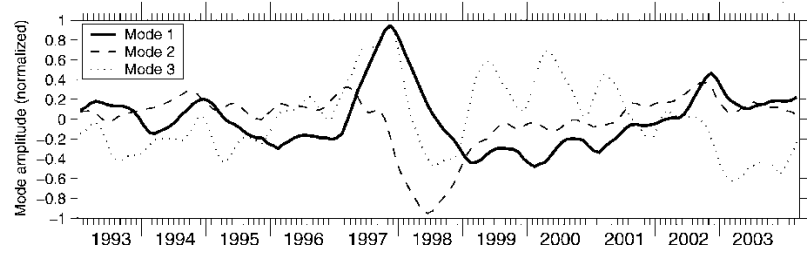

FIG. 6. EOF mode amplitudes for the modes shown in Fig. 5. Legend indicates line type definitions for each mode.

\section{Results \\ a. WWV movement described by ISSH changes}

The significant ISSH signals observed in the equatorial region were not unique; fairly large signals were observed throughout the equatorial band and into the subtropical gyre regions (Fig. 7).

The time series that make up this Hovmoeller diagram were determined by simple integration of the gridded SSHA values, with the resulting values being divided by the size of the bin. Errors in the ISSH values are reduced based on the number of grid points within each bin (which varies based on the bin size); for the large areas used herein the error in bin-averaged SSHA values should be smaller than $1 \mathrm{~cm}$ (keeping in mind that this is the accuracy of the time-varying SSHA and not the accuracy of the SSH including the time mean). There are clear signals roughly contemporaneous with the 1997-98 El Niño event reaching $15^{\circ}-20^{\circ} \mathrm{S}$ and $10^{\circ}-$ $15^{\circ} \mathrm{N}$ in both the eastern and western Pacific. The positive ISSH anomalies in the eastern Pacific are stronger in magnitude to the south of the equator, while the negative ISSH anomalies in the western Pacific are larger in magnitude to the north of the equator. As shown in Fig. 2, there are meridional transports coincident in time with these large WWV changes, demonstrating that the signals in Fig. 7 document movement of WWV about the Pacific. Poleward of $20^{\circ} \mathrm{S}$ and $15^{\circ} \mathrm{N}$ the ISSH signals are very weak, indicating that the warm water exchange from the equatorial band does not reach those higher latitudes in larger volumes.

Because the diapycnal transports across $20^{\circ} \mathrm{C}$ have been shown to be small (Meinen et al. 2001), and therefore the overall basin-scale WWV changes must balance to near zero, the decreases in WWV in the western region between $5^{\circ} \mathrm{S}$ and $15^{\circ} \mathrm{N}$ in late 1996 and early to mid 1997 (starting at $15^{\circ} \mathrm{N}$ and moving southward) indicate that the WWV buildup in the eastern equatorial Pacific prior to the 1997-98 El Niño event must have drawn warm water primarily from the western Pacific between $5^{\circ} \mathrm{S}$ and $15^{\circ} \mathrm{N}$. The fact that the buildup draws water from the west is not a surprising result; however, the meridional asymmetry of the source region for the WWV has implications for cross-equatorial transports (since the WWV that builds up is discharged to both hemispheres within the interior during El Niño). Zebiak (1989) suggested on the basis of a simple coupled 

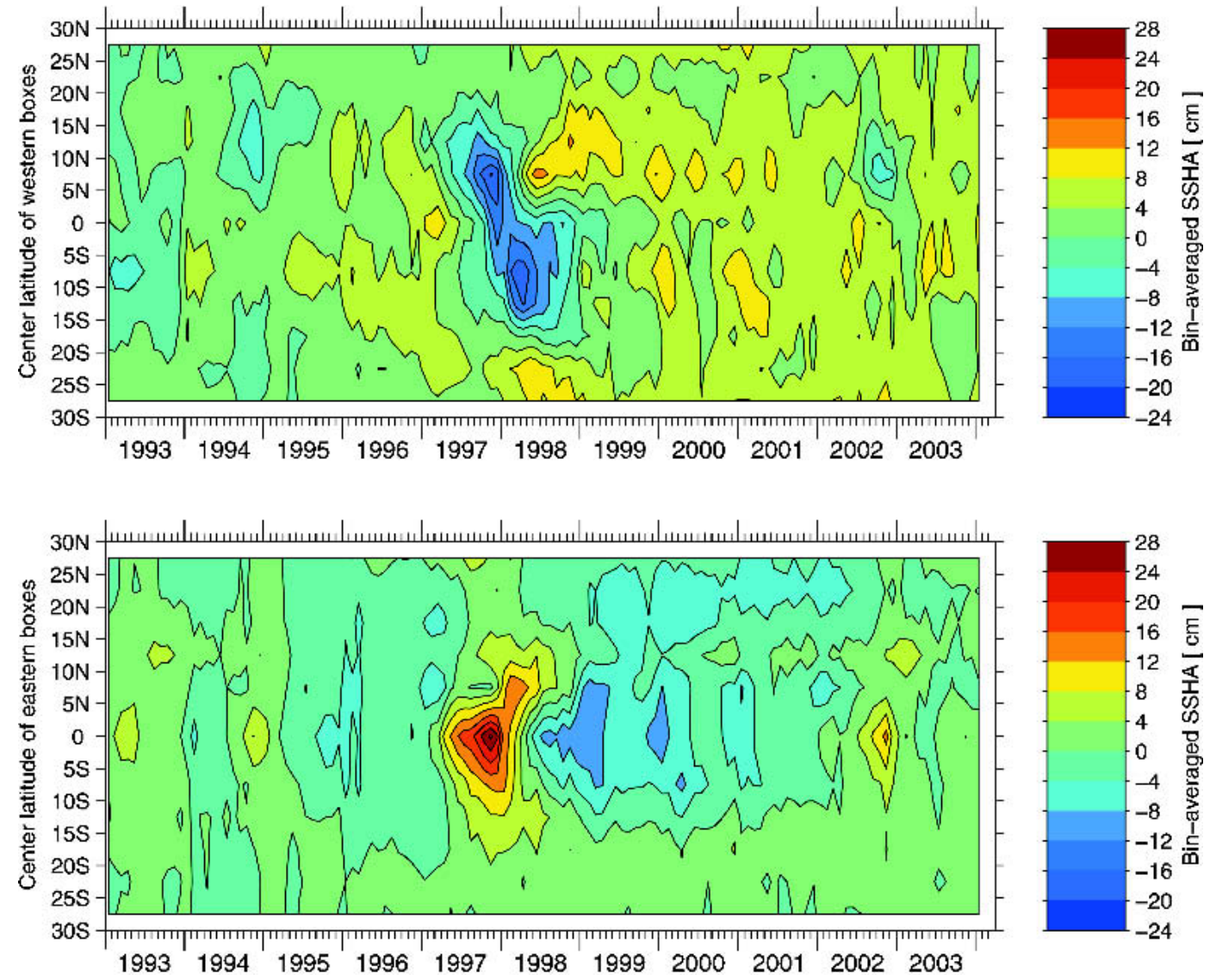

FIG. 7. Hovmoeller diagrams showing the time fluctuations of ISSH (cm) in the (top) western and (bottom) eastern boxes. Because the sizes of the various boxes are different (see text), the value of ISSH has been divided by the box surface area to facilitate comparison.

model that interhemispheric exchange occurred during the El Niño-La Niña cycle, and the asymmetry of the source region observed here provides some evidence of this interhemispheric exchange.

By late 1997, during the peak of the El Niño event (Fig. 1), the WWV in the western Pacific between $5^{\circ}$ and $15^{\circ} \mathrm{N}$ was already increasing while the WWV in the eastern equatorial Pacific was still decreasing. This suggests intensified westward transport of warm water in the North Equatorial Current and/or decreased eastward flow of warm water in the North Equatorial Countercurrent, which is confirmed by the net (geostrophic plus Ekman) zonal transport from Meinen and McPhaden (2001) within $5^{\circ}-8^{\circ} \mathrm{N}$ (not shown), which exhibited 4-8 Sv of anomalous westward transport beginning in late 1997. This anomalous westward flow occurs nearly simultaneously with a $10-20 \mathrm{~Sv}$ anomalous northward flow across $5^{\circ} \mathrm{N}$ east of $155^{\circ} \mathrm{W}$. To the south of the equator the southward transport across $5^{\circ} \mathrm{S}$ was only about $50 \%$ of the transport across $5^{\circ} \mathrm{N}$, consistent with the modeling results of Kug et al. (2003). There is no indication of anomalous westward flow between $5^{\circ}$ and $8^{\circ} \mathrm{S}$ in late 1997 ; in fact, the anomalies are eastward at that point. This clearly shows that the flow discharged to the south must go further toward the pole before turning west, consistent with the ISSH results shown in Fig. 7.

To the north the poleward flow appears to only make it as far as about $10^{\circ} \mathrm{N}$, roughly the same location as the strong atmospheric intertropical convergence zone (ITCZ) (e.g., Philander 1990). The strong ITCZ near $10^{\circ} \mathrm{N}$ in the eastern equatorial Pacific, and the associated change in the wind stress curl, may be preventing the interannual anomalies of WWV from extending farther to the north. This blocking effect was absent in the modeling results of Zebiak (1989), which exhibited exchange between the Northern Hemisphere and the Tropics extending well beyond $15^{\circ} \mathrm{N}$. However, previous studies of the time-mean STCs indicated the strong potential vorticity front located under the ITCZ in the upper ocean limited the southward flow of Northern Hemisphere subtropical water to the Tropics (e.g., Johnson and McPhaden 1999; McPhaden and Zhang 2002), and the results presented here suggest that the PV front also deflects water and keeps it from flowing northward. 


\section{b. Transports estimated directly from subsurface temperature data}

As discussed earlier, the BMRC optimal interpolation (OI) product of subsurface temperature by necessity incorporates much less data away from the equator where there are fewer measurements. In those regions the OI mapping must result in overly smooth fields, which are also likely to be less physically accurate. This was the motivation for using the SSHA data in this study of interannual variability. Assuming, however, that the errors in the BMRC OI product have a significant random component, by averaging over long enough time periods the BMRC subsurface temperatures outside the TAO array region should be more accurate. If these time-averaged subsurface temperatures can be translated into estimates of upper-ocean transport, they would provide an independent test of the circulation patterns suggested by the ISSH results. The appendix describes a method for determining upper-ocean transports from temperature data using the so-called Fofonoff potential (Fofonoff 1962). Basically the vertically averaged temperature is converted into Fofonoff potential (baroclinic streamfunction) using an empirical relationship derived from hydrography, and gradients of Fofonoff potential yield baroclinic transports. The appendix also illustrates the impact of salinity variability on the temperature-transport relationship.

Monthly upper-ocean transport maps were derived from the BMRC temperature maps as described in the appendix. To reduce the noise resulting from data limitations outside the TAO array domain, the monthly upper-ocean transports were averaged to produce a time-mean transport for the period 1993-96 as well as year-long anomaly averages (where the 1993-96 mean has been removed) for the periods centered on the 1997-98 El Niño event and the subsequent 1998-2000 La Niña event (Fig. 8).

Equatorward of $5^{\circ} \mathrm{S}$ and $5^{\circ} \mathrm{N}$ no transports were estimated, as traditional geostrophic estimation is generally accepted to be inaccurate too close to the equator where the Coriolis parameter goes to zero (e.g., Lukas and Firing 1984; Kessler and Taft 1987; Picaut and Tournier 1991; Lagerloef et al. 1999; Meinen and McPhaden 2001). This is not a significant liability since this study has sought to monitor the WWV pathways between the equatorial band and the higher latitudes, not the pathways within the equatorial band themselves where the interannual flows are already fairly well known.

The time-mean 1993-96 transport clearly shows the major current features of the interior tropical and subtropical Pacific with the westward-flowing NEC and SEC as well as eastward-flowing NECC. Mean transports are fairly weak north of $10^{\circ} \mathrm{N}$ in the eastern Pacific and south of $15^{\circ} \mathrm{S}$ in the western and central Pacific; keep in mind, however, that there are meridional flows associated with the STCs that are being obscured by the strong zonal flows. The agreement between the mean transport vectors shown in Fig. 8 and the historical picture of upper-ocean flow (e.g., Tomczak and Godfrey 1994) lends some confidence in the method used here to calculate the transports.

The anomalous transports averaged over the June 1997-May 1998 period, which corresponds to the period when WWV was lost from the Tropics during the 1997-98 El Niño event (Fig. 1), were characterized north of the equator by anomalous meridional upperocean transport toward the north out of the Tropics between $5^{\circ}$ and $10^{\circ} \mathrm{N}$ at most longitudes (except east of $95^{\circ} \mathrm{W}$ ). These transports did not seem to extend beyond $10^{\circ} \mathrm{N}$; from $10^{\circ}$ to $15^{\circ} \mathrm{N}$ the transports are almost completely zonal except for the far western Pacific. Interestingly, east of about $140^{\circ} \mathrm{W}$ the $5^{\circ}-10^{\circ} \mathrm{N}$ transport anomalies are actually eastward, suggesting either an increase in the transport of the NECC or a northward shift of the NEC. The transports to the south of the equator were characterized by anomalous southward transport between $5^{\circ}$ and $10^{\circ} \mathrm{S}$ throughout most of the basin except for the far east and west Pacific. The southward flows, however, continued nearly all the way to $20^{\circ} \mathrm{S}$ in the central Pacific. West of $160^{\circ} \mathrm{W}$ the transport between $10^{\circ}$ and $20^{\circ} \mathrm{S}$ was primarily westward with a weak northward component. These observations are consistent with the ISSH results, which indicated that the WWV discharged from the equatorial band reached much farther to the south than it did to the north and that the WWV flow toward the equator from the south in the western Pacific did not occur until the WWV discharge from the equatorial band was already underway.

The anomalous transports estimated using the BMRC temperature data and averaged over the June 1998-May 1999 period, which corresponded to the period when WWV began to recharge in the equatorial band during the 1998-2000 La Niña event, were generally much weaker than during the June 1997-May 1998 period. The trend was for westward flow over most of the basin between $5^{\circ}$ and $10^{\circ} \mathrm{N}$, with weak flows north of $10^{\circ} \mathrm{N}$, while south of the equator there was also a trend for westward flow; however the pathway was more circuitous, with part of the flow headed south to near $20^{\circ} \mathrm{S}$ in the central Pacific before turning northwestward near the date line. This is consistent with the later refilling of the western region between $5^{\circ}$ and $15^{\circ} \mathrm{S}$, as indicated in the ISSH results (Fig. 7).

The upper-ocean transport estimates tend to confirm the ISSH results shown earlier; however there are some differences. In particular, the anomalous upper-ocean transports in the eastern Pacific between $10^{\circ}$ and $20^{\circ} \mathrm{S}$ are quite weak during both the El Niño and La Niña time periods. Recall that Fig. 4 showed weak correlation between the WWV calculated from the BMRC dataset and the SSHA in that region. Whether the weak anomalous flows shown in Fig. 8 in this region are ac- 

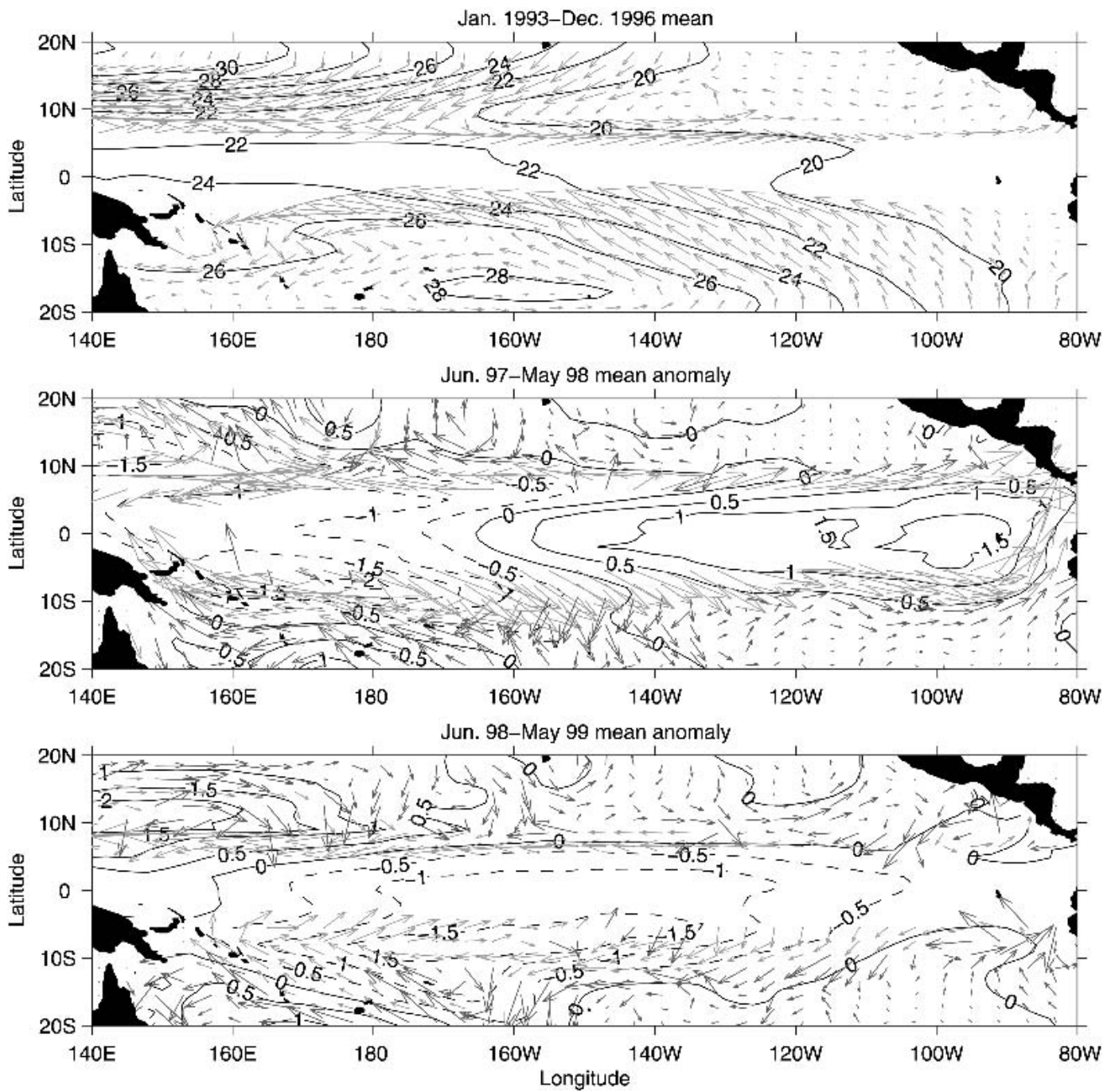

FIG. 8. Geostrophic transports within the upper $500 \mathrm{dbar}$ (relative to $500 \mathrm{dbar}$ ) in bins of $1^{\circ}$ of latitude by $2^{\circ}$ of longitude. Also shown are the contours of Fofonoff potential; arrows are parallel to the contours. Black areas indicate land. (top) Time-mean transports for 1993-96. (middle) Time-mean transport anomaly (after removal of 1993-96 mean from each monthly transport field) for Jun 1997-May 1998, representing the "discharge" period during the 1997-98 El Niño event. (bottom) Time-mean transport anomaly for Jun 1998-May 1999, representing the "recharge" period during the 1998-2000 La Niña event. Largest light gray vectors in each panel represent transports of 4.0, 2.5, and 1.6 Sv for the top, middle, and bottom panels, respectively. Darker gray arrows represent transports less than $0.5 \mathrm{~Sv}$, which have been scaled up to increase readability.

curate, or whether they are a result of a lack of data available for the BMRC data process, cannot be answered with the data at hand; however, in general, these upper-ocean transports are consistent with the ISSH results.

\section{c. Theoretical Sverdrup transports}

A second, independent test of the ISSH results presented in Fig. 7 can be made by comparing the ISSH results to the theoretical Sverdrup transports determined using wind observations (e.g., Gill 1982; Ueki et al. 2003). Both the FSU and ECMWF wind products were used to estimate the Sverdrup transport anomalies (1993-96 time mean removed); the results were generally similar from the two different wind products so only the results from the FSU wind product are shown here (Fig. 9).

Consistent with the ISSH and upper-ocean transport time series, beginning in mid-1997 there is anomalous transport away from the equator in both western and eastern regions, although the signals are stronger in the eastern portion of the basin in the north. Also similar to the ISSH and upper-ocean transport estimates, the southward transport south of the equator extends to near $20^{\circ}-25^{\circ} \mathrm{S}$ in the eastern region, while the north- 

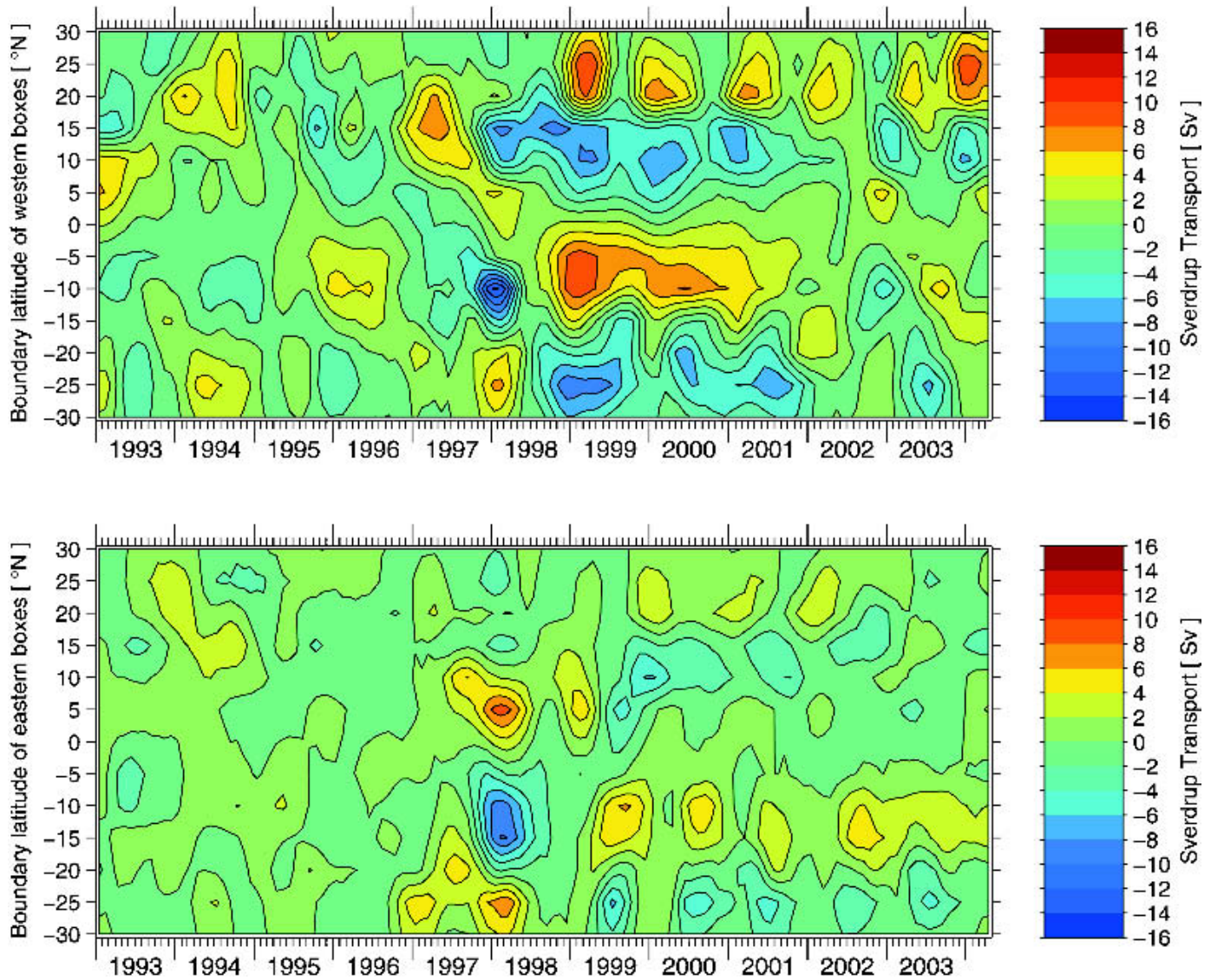

FIG. 9. Hovmoeller plot showing the theoretical Sverdrup transport anomaly (Sv, 1993-96 mean removed) calculated across latitude lines at $5^{\circ}$ increments north and south of the equator using the monthly FSU wind product for (top) western boxes and (bottom) eastern boxes. Positive transport is northward. Note transport was not calculated across the equator.

ward anomalous transports drop to zero near $10^{\circ}-12^{\circ} \mathrm{N}$. During the La Niña event in 1998-2000 the Sverdrup transport anomalies indicate strong equatorward flows in the western basin, particularly in the first part of 1999, and weak equatorward flow in the eastern basin. In the east the return flows seem to span a slightly larger range of latitudes in the south than in the north, but in the west the return Sverdrup flows seem to be bound within $15^{\circ}-20^{\circ}$ of the equator to both the north and south. There are some differences between the Sverdrup transport anomaly results and the results of the ISSH and upper-ocean transport estimates; however, the Sverdrup transport anomalies generally agree with the ISSH results (Fig. 7) and the upper-ocean geostrophic transports (Fig. 8).

\section{Conclusions}

The basic STC picture developed for the time-mean circulation, with poleward Ekman transports and equatorward geostrophic transports with communication blocked under the ITCZ in the Northern Hemisphere, seems to also hold for the interannually varying signals, at least during the large 1997-2000 El Niña-La Niña events. By monitoring the movement of warm water using ISSH as a proxy (Fig. 7), and by calculating the Sverdrup transports, which contain both upper Ekman limb and the lower geostrophic limb of the STCs, the "net" STC circulation has been quantified without decomposing that flow into the upper and lower components. The upper-ocean temperature calculations (Fig. 8), however, represent only the lower geostrophic limb of the STCs, and the anomalies of that flow are consistent with the net circulation suggested by the other datasets. This is consistent with previous work, which demonstrated that the anomalous poleward flows associated with El Niño-La Niña events are more heavily influenced by geostrophic transport anomalies than Ekman anomalies (Zebiak 1989; Meinen and McPhaden 2001). Meinen et al. (2001) have demonstrated that the vertical velocity signal on the equator also exhibits strong interannual variations, and these variations are consistent with the poleward Ekman and equatorward geostrophic flows discussed herein. Anomalous tropi- 
cal-subtropical exchange seems to be stifled north of the equator by the potential vorticity front under the ITCZ, while south of the equator the exchange reaches $20^{\circ}-25^{\circ} \mathrm{S}$.

Another interesting result of this study is the existence of a phase difference between the Northern and Southern Hemisphere interannual circulations associated with ENSO. The inflow of warm water toward the equator in the western Pacific prior to El Niño, as well as the refilling of the western subtropical Pacific during the 1997-98 El Niño event, occurs roughly 6-8 months earlier in the Northern Hemisphere than in the Southern Hemisphere. This phase difference is independent of the annual (seasonal) cycle, which has been removed prior to all of the analyses shown herein. This phase difference is consistent with the hemispheric exchange proposed by Zebiak (1989) based on a simple coupled model, although in Zebiak's model the exchange reached much farther into the Northern Hemisphere. The phase difference between the ENSO related circulations may also indicate a phase difference between the Northern and Southern Hemisphere STCs, although additional work will be required to confirm this result. This also has implications for previous studies of the STCs, which often used either snapshot data or irregularly sampled data (in a temporal sense) to determine the time-mean pathways for the STCs. Models and (limited) observations have indicated that the western boundary current regimes are dominated by and out of phase with the interior flows (e.g., Lee and Fukumori 2003; Ueki et al. 2003) and some models indicate that the interior flow dominates whether the Indonesian Throughflow is present or not (Lee and Fukumori 2003). This suggests that the observed phase difference is likely due to the asymmetry of the wind pattern (e.g., Kug et al. 2003); however this is clearly an area for future research.

Acknowledgments. The author thanks the following people for providing the data used in this study, either personally or via their Web sites: J. J. O'Brien and D. M. Legler of The Florida State University for the FSU wind pseudostress data; the European Centre for Medium-Range Weather Forecasts for the ECMWF wind data; Neville Smith, BMRC, Australia, for the gridded subsurface temperature data; and the many scientists at the Pacific Marine Environmental Laboratory who over the 1990s helped to collect the CTD data used herein. Dai McClurg and Paul Freitag at PMEL kindly helped in the acquisition of the most recent upperocean temperature data. The altimeter products were produced by the CLS Space Oceanography Division as part of the Environment and Climate EU ENACT Project (EVK2-CT2001-00117) and with support from CNES; the data were downloaded from the CLS Web page. Bob Molinari, Rick Lumpkin, Derrick Snowden, and the anonymous reviewers provided a number of helpful suggestions for improving this manuscript, and their assistance is greatly appreciated. This study was funded under NSF Grant OCE01-36355.

\section{APPENDIX}

\section{Calculating Transports from Upper-Ocean Temperatures}

The first concern about using subsurface temperature to estimate transports is the lack of salinity information. Salinity variability can have significant impacts on density and, hence the pressure gradients associated with geostrophic transports, although some modeling studies in this region have suggested that the effect of salinity variability on velocity is small (Kug et al. 2003). To test the importance of salinity variability in the tropical and subtropical Pacific, 4304 conductivity-temperaturedepth (CTD) profiles from the region were gathered (Fig. A1).

All of these CTDs were obtained during the 1990s and they represent profiles which were obtained on many different ships by different investigators. These CTD profiles were used to test whether subsurface temperature provides sufficient information to estimate the upper-ocean transports in this region. To do this, each CTD profile was used to estimate the heat content $(q)$ integrated in the upper 500 dbar (constant values of density, $\rho=1030 \mathrm{~kg} \mathrm{~m}^{-3}$, and specific heat, $C_{p}=3995$ $\mathrm{J} \mathrm{kg}^{-1}{ }^{\circ} \mathrm{C}^{-1}$, were used in the integration) via the equation $q=\int_{500}^{0} \rho C_{p} T d z$. Each CTD was also used to calculate the potential energy anomaly $(\chi)$, sometimes also called the Fofonoff potential (Fofonoff 1962), which was also integrated over the upper 500 dbar via

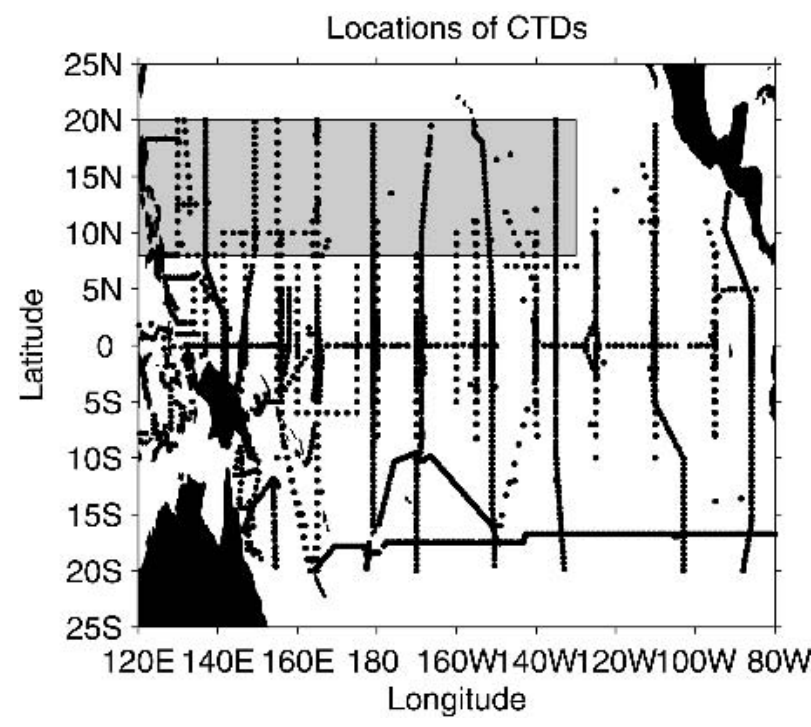

FIG. A1. Location of the CTDs used in developing the Fofonoff potential $(\chi)$ vs heat content $(q)$ relationship. Gray area represents the small subregion where the $\chi$ vs $q$ was fit separately (see text). Black areas represent land. 


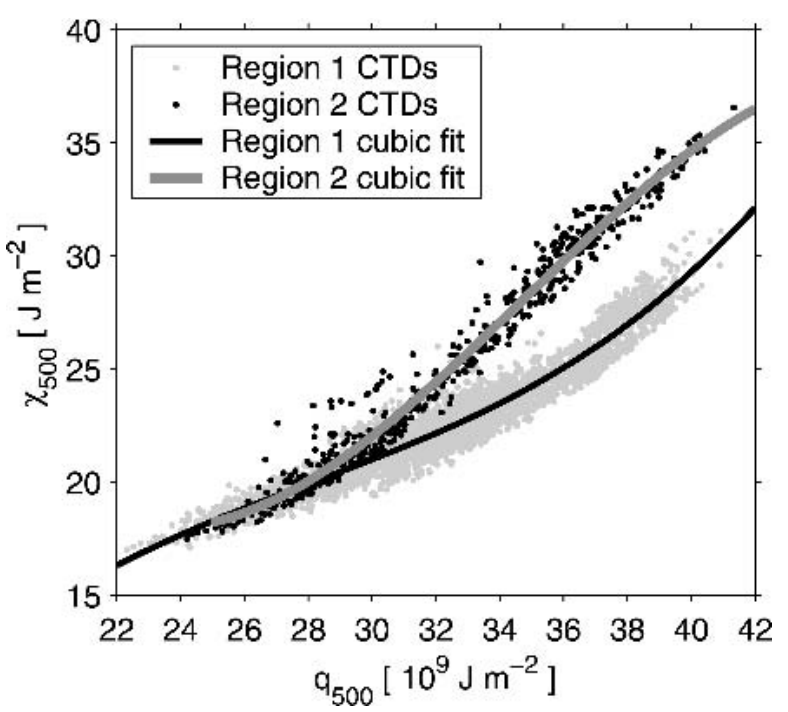

FIG. A2. Relationship between Fofonoff potential $(\chi)$ and heat content $(q)$. Both quantities are integrated within the upper 500 dbar; all values are determined from the CTDs in Fig. 10. Black dots represent CTDs within the small highlighted subregion in Fig. 10; gray dots represent the remaining CTDs. Solid lines represent cubic polynomial fits to the $\chi$ vs $q$ relationships.

the equation $\chi=g^{-1} \int_{0}^{500} p^{\prime} \delta d p^{\prime}$, where $g, p$, and $\delta$ are gravity, pressure, and specific volume anomaly, respectively.

Horizontal differences of $\chi$ between two points are proportional to the component of the geostrophic relative transport perpendicular to the line between those two points [transport $=(\rho f)^{-1}\left(\chi_{2}-\chi_{1}\right)$ ], and so, if tight relationships between $q$ and $\chi$ can be developed, then the BMRC subsurface temperature can provide sufficient information to obtain estimates of the upperocean transport. Comparison of the CTD estimated $q$ and $\chi$ values indicates that there is a fairly tight relationship between the two quantities; however, the relationship appears to have two different "modes" (Fig. A2).

There is a marked regionality to the relationships: the majority of the CTDs fall upon a single relationship (gray dots), while CTDs taken north of $8^{\circ} \mathrm{N}$ and west of $130^{\circ} \mathrm{W}$ fall upon a second relationship (black dots). There are only a few outliers in the two regions, suggesting again that the potential vorticity front under the ITCZ and/or the front associated with the North Equatorial Countercurrent represents a line of demarcation between different dynamical/watermass regimes. East of $130^{\circ} \mathrm{W}$ and north of $8^{\circ} \mathrm{N}$ the observed heat contents are all within the low $q$ range wherein the two relationships overlay one another in Fig. A2, and so those casts were not broken out into the secondary group. The relationships are not particularly sensitive to the precise choice of boundaries between the two CTD subsets; varying the locations of the boundaries by $1^{\circ}$ or $2^{\circ}$ of latitude and $/$ or $10^{\circ}$ of longitude produces little difference.
These two relationships provide a method for estimating $\chi$ from estimates of $q$; assuming a constant density $\left(\rho=1030 \mathrm{~kg} \mathrm{~m}^{-3}\right)$ and a constant specific heat $\left(C_{p}=3995 \mathrm{~J} \mathrm{~kg}^{-1}{ }^{\circ} \mathrm{C}^{-1}\right)$ the subsurface temperature values from the BMRC dataset can be vertically integrated to yield gridded maps of heat content $q$ in the upper $500 \mathrm{dbar}$. Combining these maps with the polynomial relationships fit in Fig. A2 results in maps of $\chi$; calculating gradients of $\chi$ provides monthly maps of baroclinic geostrophic transports.

\section{REFERENCES}

Alory, G., and T. Delcroix, 2002: Interannual sea level changes and associated mass transports in the tropical Pacific from TOPEX/Poseidon data and linear model results (1964-1999). J. Geophys. Res., 107, 3153, doi:10.1029/2001JC001067.

Bonjean, F., and G. S. E. Lagerloef, 2002: Diagnostic model and analysis of the surface currents in the tropical Pacific Ocean. J. Phys. Oceanogr., 32, 2938-2954.

Coles, V. J., and M. M. Rienecker, 2001: North Pacific subtropical-tropical gyre exchanges in the thermocline: Simulations with two isopycnic OGCMs. J. Phys. Oceanogr., 31, 25902611.

Emery, W. J., and R. E. Thomson, 1997: Data Analysis Methods in Physical Oceanography. Pergamon Press, 634 pp.

Fofonoff, N. P., 1962: Dynamics of ocean currents. The Sea, M. N. Hill, Ed., Physical Oceanography, Vol. 1, John Wiley and Sons, 323-395.

Gill, A. E., 1982: Atmosphere-Ocean Dynamics. Academic Press, $662 \mathrm{pp}$.

Huang, B., and Z. Liu, 1999: Pacific subtropical-tropical thermocline water exchange in the National Centers for Environmental Prediction ocean model. J. Geophys. Res., 104, 11 065-11076.

Jin, F.-F., 1997a: An equatorial ocean recharge paradigm for ENSO. Part I: Conceptual model. J. Atmos. Sci., 54, 811-829.

_ 1997b: An equatorial ocean recharge paradigm for ENSO. Part II: A stripped-down coupled model. J. Atmos. Sci., 54, 830-847.

Johnson, G. C., and M. J. McPhaden, 1999: Interior pycnocline flow from the subtropical to the equatorial Pacific Ocean. $J$. Phys. Oceanogr., 29, 3073-3089.

Kessler, W. S., and B. A. Taft, 1987: Dynamic heights and zonal geostrophic transports in the central tropical Pacific during 1979-84. J. Phys. Oceanogr., 17, 97-122.

Kleeman, R., J. P. McCreary Jr., and B. A. Klinger, 1999: A mechanism for generating ENSO decadal variability. Geophys. Res. Lett., 26, 1743-1746.

Klinger, B. A., and J. Marotzke, 2000: Meridional heat transport by the subtropical cell. J. Phys. Oceanogr., 30, 696-705.

Kug, J.-S., I.-S. Kang, and S.-I. An, 2003: Symmetric and antisymmetric mass exchanges between the equatorial and offequatorial Pacific associated with ENSO. J. Geophys. Res., 108, 3284, doi:10.1029/2002JC001671.

Lagerloef, G. S. E., G. T. Mitchum, R. B. Lukas, and P. P. Niiler, 1999: Tropical Pacific near-surface currents estimated from altimeter, wind, and drifter data. J. Geophys. Res., 104, $23313-23326$.

Lee, T., and I. Fukumori, 2003: Interannual-to-decadal variations of tropical-subtropical exchange in the Pacific Ocean: Boundary versus interior pycnocline transports. J. Climate, 16, 4022-4042.

Liu, Z., 1994: A simple model of the mass exchange between the subtropical and tropical ocean. J. Phys. Oceanogr., 24, 11531165.

— , S. G. H. Philander, and R. C. Pacanowski, 1994: A GCM 
study of tropical-subtropical upper ocean water exchange. $J$. Phys. Oceanogr., 24, 2606-2623.

Lukas, R., and E. Firing, 1984: The geostrophic balance of the Pacific Equatorial Undercurrent. Deep-Sea Res., 31A, 61-66.

Mayer, D. A., R. L. Molinari, M. O. Baringer, and G. J. Goni, 2001: Transition regions and their role in the relationship between sea surface height and subsurface temperature structure in the Atlantic Ocean. Geophys. Res. Lett., 28, 3943-3946.

McCreary, J. P., Jr., and P. Lu, 1994: Interaction between the subtropical and equatorial ocean circulations: The subtropical cell. J. Phys. Oceanogr., 24, 466-497.

McPhaden, M. J., and D. Zhang, 2002: Slowdown of the meridional overturning circulation in the upper Pacific Ocean. $\mathrm{Na}$ ture, 415, 603-608.

— , and Coauthors, 1998: The Tropical Ocean Global Atmosphere (TOGA) observing system: A decade of progress. $J$. Geophys. Res., 103, 14 169-14 240.

Meinen, C. S., and M. J. McPhaden, 2000: Observations of warm water volume changes in the equatorial Pacific and their relationship to El Niño and La Niña. J. Climate, 13, 3551-3559.

- , and - 2001: Interannual variability in warm water volume transports in the equatorial Pacific during 1993-1999. J. Phys. Oceanogr., 31, 1324-1345.

- _ - and G. C. Johnson, 2001: Vertical velocities and transports in the equatorial Pacific during 1993-99. J. Phys. Oceanogr., 31, 3230-3248.

Nonaka, M., S.-P. Xie, and J. P. McCreary, 2002: Decadal variations in the subtropical cells and equatorial Pacific SST. Geophys. Res. Lett., 29, 1116, doi:10.1029/2001GL013717.

Pedlosky, J., 1991: The link between western boundary currents and Equatorial Undercurrents. J. Phys. Oceanogr., 21, 15531558.

Philander, S. G. H., 1990: El Niño, La Niña, and the Southern Oscillation. Academic Press, 293 pp.

Picaut, J., and R. Tournier, 1991: Monitoring the 1979-1985 equatorial Pacific current transports with expendable bathythermograph data. J. Geophys. Res., 96, 3263-3277.
Rothstein, L. M., R.-H. Zhang, A. J. Busalacchi, and D. Chen, 1998: A numerical simulation of the mean water pathways in the subtropical and tropical Pacific Ocean. J. Phys. Oceanogr., 28, 322-343.

Sirven, J., C. Frankignoul, S. Février, N. Sennéchael, and F. Bonjean, 1998: Two-layer model simulations using observation and model-based wind stresses of the 1985-1992 thermocline depth anomalies in the tropical Pacific. J. Geophys. Res., 103, $21367-21383$.

Smith, N. R., 1995a: The BMRC ocean thermal analysis system. Aust. Meteor. Mag., 44, 93-110.

_ 1995b: An improved system for tropical ocean subsurface temperature analyses. J. Atmos. Oceanic Technol., 12, 850870

_- , and G. Meyers, 1996: An evaluation of expendable bathythermograph and Tropical Atmosphere-Ocean Array data for monitoring tropical ocean variability. J. Geophys. Res., 101, 28 489-28 501.

Tomczak, M., and J. S. Godfrey, 1994: Regional Oceanography: An Introduction. Pergamon, $422 \mathrm{pp}$.

Trenberth, K. E., 1997: The definition of El Niño. Bull. Amer. Meteor. Soc., 78, 2771-2777.

_, and T. J. Hoar, 1996: The 1990-1995 El Niño-Southern Oscillation event: Longest on record. Geophys. Res. Lett., 27, $57-60$.

—, and J. M. Caron, 2001: Estimates of meridional atmosphere and ocean heat transports. J. Climate, 14, 3433-3443.

Ueki, I., Y. Kashino, and Y. Kuroda, 2003: Observations of current variations off the New Guinea coast including the 1997-1998 El Niño period and their relationship with Sverdrup transport. J. Geophys. Res., 108, 3243, doi:10.1029/ 2002JC001611.

Wyrtki, K., 1975: Fluctuations in the dynamic topography in the Pacific Ocean. J. Phys. Oceanogr., 5, 450-459.

Zebiak, S. E., 1989: Oceanic heat content variability and El Niño cycles. J. Phys. Oceanogr., 19, 475-486. 